\title{
RADIOCARBON AGE OF VERTISOLS AND ITS INTERPRETATION USING DATA ON GILGAI COMPLEX IN THE NORTH CAUCASUS
}

\author{
Irina Kovda ${ }^{1}$ Warren Lynn $^{2} \bullet$ Dewayne Williams ${ }^{2} \bullet$ Olga Chichagova $^{1}$ \\ ABSTRACT. Radiocarbon dates were analyzed to assess Vertisols age around the world. They show an increase of radiocar- \\ bon age from mainly modern-3000 BP in 0-100 cm layer up to $10,000 \mathrm{BP}$ at a depth $100-200 \mathrm{~cm}$. Older dates reflect the age \\ of parent material. The inversion of ${ }^{14} \mathrm{C}$ dates seems to be a frequent phenomenon in Vertisols. A series of new dates of Ver- \\ tisols from gilgai microhigh, microslope and microlow in the North Caucasus was done in order to understand the nature of \\ this inversion. ${ }^{14} \mathrm{C}$ age in the gilgai soil complex ranges from $70 \pm 45 \mathrm{BP}$ in the microlow to $5610 \pm 180 \mathrm{BP}$ in the microhigh. \\ A trend of similar depths being younger in the microslope and microlow was found. We explain this by intensive humus reju- \\ venation in the microlows due to water downward flow. The older date in the microhigh represents the old humus horizon \\ sheared laterally close to the surface and preserved by impermeable water regime. We explain inversions of ${ }^{14} \mathrm{C}$ age-depth \\ curves by the sampling procedures. In a narrow pit, genetically different parts of former gilgai could easily be as a genetically \\ uniform soil profile. Because of this strong microvariability, Vertisols require sampling in a trench accounting for gilgai ele- \\ ments, even when gilgai are not obvious.
}

\section{INTRODUCTION}

Vertisols are known as unique soils with a set of peculiar properties and processes. Among the questions that arise when studying Vertisols are: what is the rate of pedoturbation, how does it affect Vertisols, are Vertisols young or old soils? The first publications postulated a strong homogenization of the Vertisol profile (Dudal 1965). Later, investigations of Yaalon and Kalmar (1978), Wilding and Tessier (1988) have shown the priority of shear planes formation under pedoturbation. It was shown by profile distribution of physico-chemical and morphological properties (Wilding et al. 1990), as well as by radiocarbon dating (Yaalon and Kalmar 1978; Blackburn et al. 1979). Also, in case of a gilgai microrelief a strong spatial differentiation was found (Beckmann et al. 1970; Wilding et al. 1990; Kovda et al. 1992). Our personal data show that spatial microvariability is characteristic of Vertisols. It appears before gilgai formation and is the most pronounced when gilgai exist for a long time. Microvariability stays for the long time even when the gilgai are destroyed by natural or artificial processes (Kovda et al. 1999).

The objectives of our investigation were 1) to summarize and analyze the published radiocarbon dates of Vertisols; 2) to obtain new radiocarbon data for gilgai complex in the North Caucasus; 3 ) to present a pedogenic model explaining these results.

\section{MATERIALS AND METHODS}

\section{Study Area}

Vertisols with gilgai microrelief were studied in the North Caucasus in the southeastern part of the Stavropol Upland $\left(44^{\circ} 38^{\prime} 17^{\prime \prime} \mathrm{N}, 42^{\circ} 15^{\prime} 04^{\prime \prime} \mathrm{E}\right)$ in Russia. The study site is at an elevation of $470 \mathrm{~m}$. This area has a temperate continental climate, with a mean July temperature of $+21^{\circ} \mathrm{C}$, and a mean January temperature of about $-4^{\circ} \mathrm{C}$. Average annual precipitation is $500 \mathrm{~mm}$ with a dry season from July to October. Soils are formed on eluvium-deluvium of Neogene marine clays under native steppe vegetation. Vegetation has different composition and productivity according to microrelief. Normal gilgai have an amplitude of $0.3-0.5 \mathrm{~m}$ and include microlows, microslopes and microhighs with a distance from the microhigh to the microlow of about 3-5 m.

${ }^{1}$ Institute of Geography, Russian Academy of Sciences, Staromonetny 29, 109017 Moscow, Russia. Email: komo@rc.msu.ru

${ }^{2}$ Natural Resources Conservation Service, USA

(C) 2001 by the Arizona Board of Regents on behalf of the University of Arizona

Radiocarbon, Vol 43, Nr 2B, 2001, p 603-609

Proceedings of the 17 th International ${ }^{14} \mathrm{C}$ Conference, edited by I Carmi and E Boaretto 
The soils investigated are very fine, mixed, active mesic Sodic Haplusterts on microhighs (pedon also meets the criteria for Chromic Haplusterts), very fine, mixed, superactive mesic Sodic Haplusterts on the microslopes, and very fine, mixed, superactive, mesic Typic Epiaquerts in the microlows (Soil Survey Staff 1998). Subsoil material displaces parts of the horizontal layers in the microhigh (Figure 1).

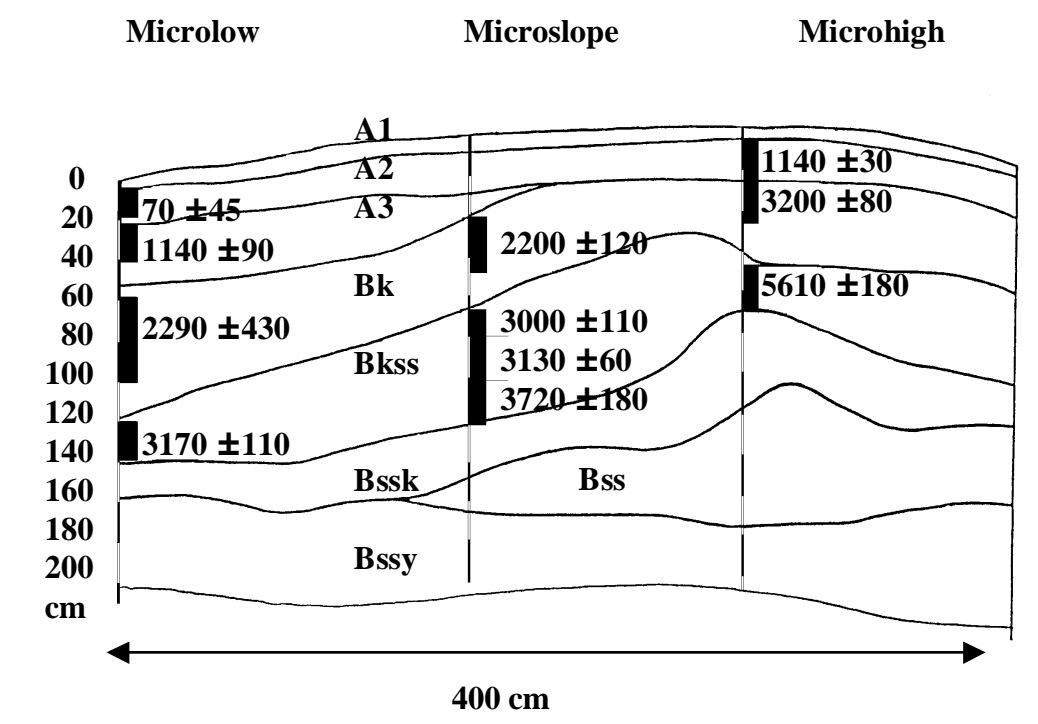

Figure 1 Cross-sectional profile of gilgai microrelief showing soil horizons and ${ }^{14} \mathrm{C}$ dates (BP). Black bars $=$ sampling for ${ }^{14} \mathrm{C}$.

\section{Field and Laboratory Methods}

Three soils were described and sampled in a trench along their vertical profiles. All morphologic horizons in the microlow, microslope and microhigh were sampled for determination of physicchemical properties (Kovda et al. 1992, 1996a, 1996b). Special samples about $3 \mathrm{~kg}$ weight were placed in plastic bags for radiocarbon dating. The polygons method (Williams et al. 1996) was also used for field description.

Soil samples were analyzed for ${ }^{14} \mathrm{C}$ age at the Institute of Geography, Russian Academy of Sciences (Lab. Nos. IGAN: 1676, 1677, 1679, 1680, 1696, 1749, 1830, 1831, 1842, 1843, 1951). ${ }^{14} \mathrm{C}$ dates were obtained for humic acids, which dominate in these soils. The dominant fraction of OM is known to provide the best dates because it is the most stable in enduring continual accumulation of more recent deposits (Chichagova and Cherkinsky 1993). Prior to the ${ }^{14} \mathrm{C}$ analyses, roots and plant debris were removed by sieving and flotation, carbonates were removed by repeated treatment with 1.0 M HCl until complete decalcination. Humus acids were repeatedly extracted with hot $0.1 \mathrm{~N}$ $\mathrm{NaOH}$. Humic acids were precipitated with $\mathrm{H}_{2} \mathrm{SO}_{4}$ in $\mathrm{pH}$ of $1-2$, washed acid free and dried (Chichagova 1985; Goryachkin at al. 2000). The liquid scintillation counting method was used for ${ }^{14} \mathrm{C}$ measurements by $\beta$-spectrometer "IGAN" and "Mark-11-Nuclear Chicago". The ${ }^{14} \mathrm{C}$ dates are presented in BP. Organic C content was measured by the Walkey-Black wet combustion method (Soil Survey Laboratory Methods Manual 1996). 
We used the published data of the last 30 years and we analyzed about 40 Vertisols and more than 270 dates of organic matter (OM) representing Vertisols of South and East Europe, Asia, South America, and Australia.

\section{RESULTS AND DISCUSSION}

\section{Analysis of Published ${ }^{14} \mathrm{C}$ Data of Vertisols}

Most dates indicate a Holocene age of Vertisols ( $<10,000 \mathrm{BP})$. The higher ages mainly characterize the deepest horizons, parent and underlying material, with ${ }^{14} \mathrm{C}$ dates $11-19 \mathrm{ka} \mathrm{BP}$. The ${ }^{14} \mathrm{C}$ dates for the upper $100 \mathrm{~cm}$ are mainly situated in the interval 0-3 ka BP; at a depth of 100-200 $\mathrm{cm}$ the dates are mainly shifted to 3-6 ka BP (Figure 2).

A general systematic increase of ${ }^{14} \mathrm{C}$ age with depth was found. The same trend was already known for Israeli Vertisols as described by Yaalon and Kalmar (1978). We found the confirmation of this trend for Vertisols of different regions of the world. Profile distribution of ${ }^{14} \mathrm{C}$ dates does not reveal the homogenization of radiocarbon age due to pedoturbation.

At the same time 15 of 40 profiles, i.e. more than $1 / 3$ of the analyzed Vertisols, have shown a peculiar distribution of ${ }^{14} \mathrm{C}$ data with depth. We found an "inversion" of ${ }^{14} \mathrm{C}$ dates: a set of intermediate soil horizons that has older organic matter than the underlying horizon(s) (Figure 3).

The horizons with older $\mathrm{OM}$ were found at depths ranging from $20-24 \mathrm{~cm}$ up to $100-130 \mathrm{~cm}$. Among 20 inverse dates, three were found at a depth above $40 \mathrm{~cm}$, four below $100 \mathrm{~cm}$, and 13 at a depth from 40 to $100 \mathrm{~cm}$. Our previous morphological experience have shown that in deep mature (old, developed) Vertisols these parts of the profile have a very complicated humus profile. In addition to the above-mentioned objectives we had to explain this ${ }^{14} \mathrm{C}$ inversion.

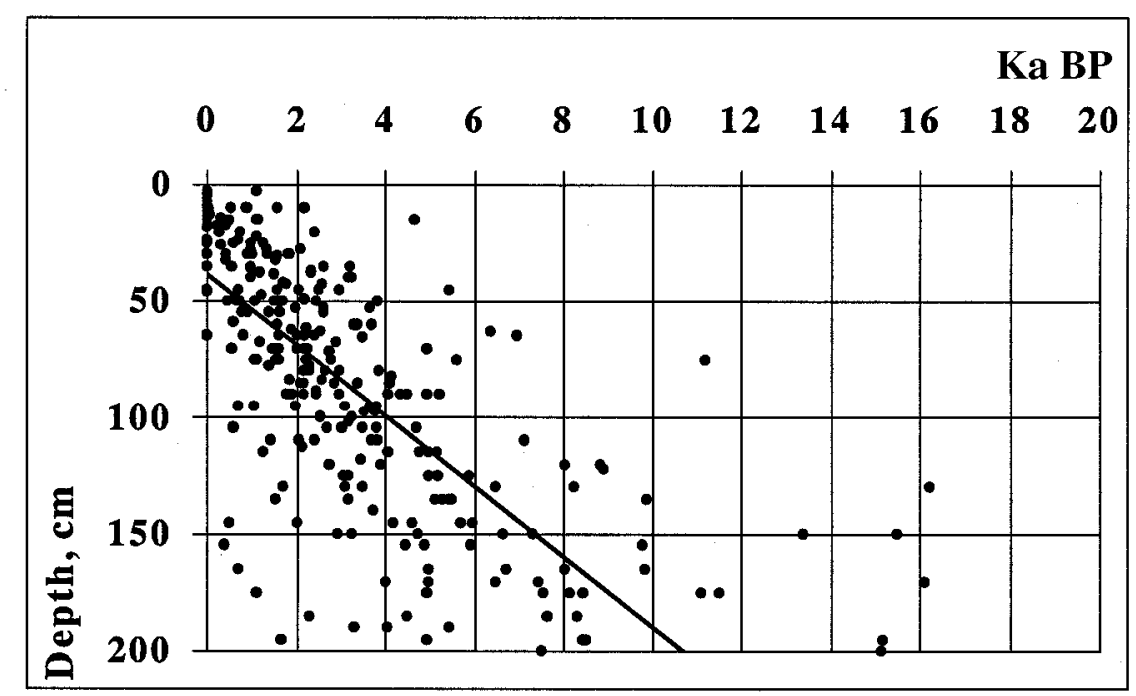

Figure $2{ }^{14} \mathrm{C}$ age of Vertisols (data from Scharpenseel and Pietig 1973a, 1973b; Arai et al. 1996; Stephan et al. 1983). 


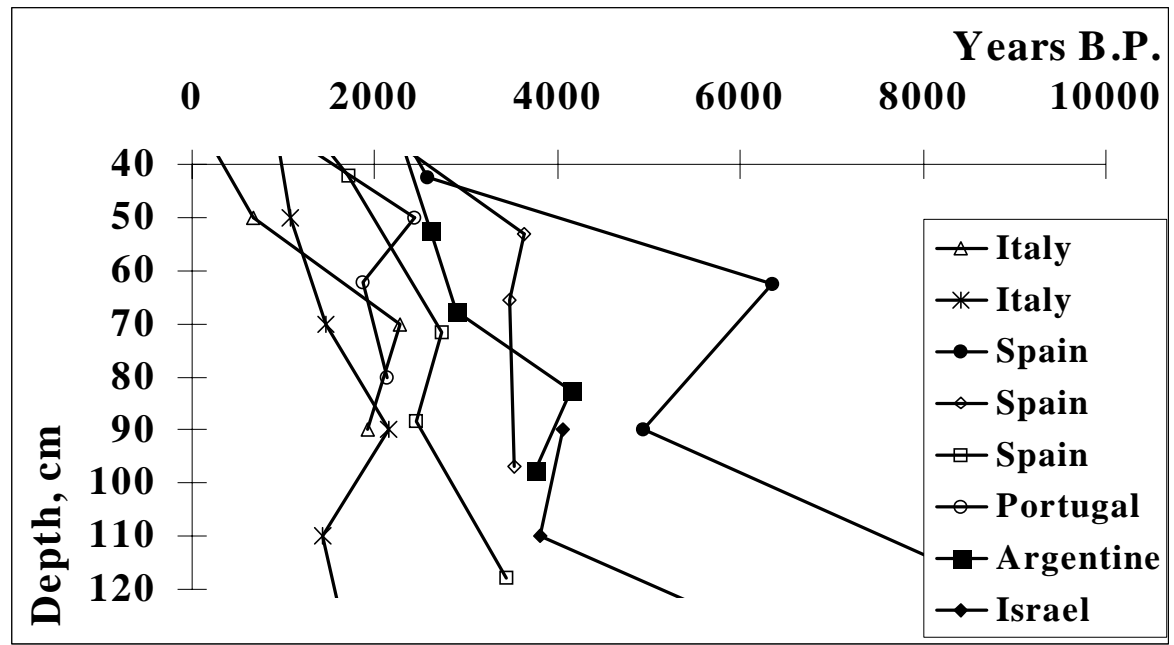

Figure 3 Selected examples of ${ }^{14} \mathrm{C}$ inversion (data from Scharpenseel and Pietig 1973b; Arai et al. 1996; Stephan et al. 1983).

\section{${ }^{14} \mathrm{C}$ Dates in Gilgai Soil Complex, North Caucasus}

Organic and inorganic $\mathrm{C}$ content in selected horizons is shown in Table $1 .{ }^{14} \mathrm{C}$ dates are presented in Figure 1. We found a normal increase of ${ }^{14} \mathrm{C}$ dates with depth in all three profiles. The radiocarbon dates for the soils range from $72 \pm 45 \mathrm{BP}$ in the upper horizon of the microlow, to $5610 \pm 180 \mathrm{BP}$ at a depth $60-90 \mathrm{~cm}$ in the soil of the microhigh. So the oldest ${ }^{14} \mathrm{C}$ age was found not in the deepest humus horizon of the microcatena. The ${ }^{14} \mathrm{C}$ age of the deepest specimen of humus horizon (125-155 $\mathrm{cm}$, microslope) was $3720 \pm 180 \mathrm{BP}$. In general the trend for the ${ }^{14} \mathrm{C}$ data of the microcatena is 70 $1440 \mathrm{BP}$ in the 0-40 cm layer, 2200-5610 BP in the layer 40-90 cm, and 3130-3720 BP in the layer below $100 \mathrm{~cm}$. The ${ }^{14} \mathrm{C}$ dates tend to be younger towards the microlow. For example, the ${ }^{14} \mathrm{C}$ data of the Bkss horizon changes from $5610 \pm 180 \mathrm{BP}$ on the microhigh to $3720 \pm 180 \mathrm{BP}$ in the microslope and to $3170 \pm 110 \mathrm{BP}$ in the microlow. A similar trend of ${ }^{14} \mathrm{C}$ age of humus in soils of microlows when compared with gilgai microhighs was noticed in Australia (Scharpenseel and Pietig 1973b; Blackburn et al. 1979).

Two interpretations of this phenomenon are possible. We explain it by modern functioning and history of gilgai evolution The first is rejuvenation by water downward flow in microlows; the second is conservation due to inclined shearing in the microhighs. Because of water redistribution in the microcatena, soils of the microslope and microlow receive more water from precipitation and snowmelt and are ponded for several months in the spring. The water penetrates to a depth of 160-180 cm in these soils and causes rejuvenation of ${ }^{14} \mathrm{C}$ ages. We could expect the humus from soils of microslope and microlow to be at least 2500-3000 years older according to the coefficient of mineralization (Cherkinsky and Brovkin 1993) or index of humus rejuvenation (Alexandrovsky and Chichagova 1998). In this case the ${ }^{14} \mathrm{C}$ age for humus of soils from microslope and microlow will roughly correspond to that from soil of the microhigh. So we can expect that these soils are perhaps older than 5610 years and may hold information on the paleoenvironment of the whole Holocene. 
Table 1 Organic and inorganic carbon content in selected horizons

\begin{tabular}{lccc}
\hline Horizon & $\begin{array}{c}\text { Depth } \\
(\mathrm{cm})\end{array}$ & $\begin{array}{c}\text { Inorganic } \\
\text { carbon }(\%)\end{array}$ & $\begin{array}{c}\text { Organic } \\
\text { carbon }(\%)\end{array}$ \\
\hline Microhigh & & & \\
A2 & $7-26$ & 0.61 & 1.75 \\
Bk & $26-57$ & 0.80 & 1.15 \\
Bkss & $57-90$ & 1.07 & 0.87 \\
Microslope & & & \\
Bk & $45-76$ & 0 & 1.89 \\
Bkss & $76-95$ & 0.12 & 1.82 \\
Bkss & $95-116$ & 0.42 & 1.40 \\
Bkss & $116-144$ & 0.70 & 1.12 \\
Microlow & & & \\
A2 & $8-23$ & 0 & 5.11 \\
A3 & $23-58$ & 0 & 2.56 \\
Bk & $58-113$ & 0 & 1.89 \\
Bkss & $113-145$ & 0.53 & 1.23 \\
\hline
\end{tabular}

The youngest age of soil OM in the upper part of the microlow is also explained by maximal input of modern OM because of highest biological productivity and deepest root system here, and by additional $\mathrm{OM}$ denudation from the gilgai microhighs.

We have also to consider the shrink-swell phenomenon characteristic for Vertisols. Wavy horizontal geometry and a microtopography were best explained by theory of shear failure (Wilding and Tessier 1988). Thus, deep material was slowly thrust into the center of the microhigh to a minimum depth of $20 \mathrm{~cm}$ below the surface. In a mature soil a part of deep humus horizon underlaid by shear plane was also thrust upward (Figure 1). That could explain the fact that the oldest radiocarbon age of $5610 \pm 180 \mathrm{BP}$ was found at a depth of $60-90 \mathrm{~cm}$ in the microhigh. This idea is supported by the relatively old date of the upper horizon in the microhigh. In addition, the impermeable water regime supports the preservation of old humus in the soil of the microhigh.

\section{Inversed ${ }^{14} \mathrm{C}$ Dates in Vertisols}

The phenomenon of inversed ${ }^{14} \mathrm{C}$ dates was found in various soils and often explained by modern OM "contamination" by groundwater or surface water penetrating into soil, as well as by penetration of young OM via windthrow, deluvium, cryoturbation, solifluxion, or anthropogenic processes (Arai et al. 1996; Chichagova 1985). In case of Vertisols it was also explained by penetration of surface OM into the cracks (Scharpenseel and Pietig 1973b). We would like to suggest another possible mechanism for inversed dates of Vertisols.

Our previous investigations have shown a strong spatial microvariability of physical and chemical properties in Vertisols with gilgai. We found the microvariability even in Vertisols without microrelief. The churning and mixing which could lead to homogenization were not found to be significant. Opposite, the lateral movement of solid and liquid phases led to very complicated internal structure of soil cover in Vertisol areas reflected by soils characteristics. Extremely complicate situation was noticed for former and present gilgai microhighs. That is why we elaborated for Vertisols a special method of description and sampling. 
In fact, the traditional sampling when someone take the samples of horizontal layers or of the most expressed zones could lead to the confusion, especially when sampling in an "ordinary" narrow soil pit. The most plausible reason for inversed ${ }^{14} \mathrm{C}$ dates seems to be the sampling of sheared horizons or samples, belonging to genetically various parts of Vertisols.

Some other mechanisms of humus rejuvenation and inversed dates should be mentioned for Vertisols: excessive deposits of surface material in dry-season cracks as expected by Scharpenseel and Pietig (1973b); internal migration of solutions containing dissolved OM; secondary active shearing after a long period of mechanical stability. These mechanisms can lead to more complicated ${ }^{14} \mathrm{C}$ vertical profiles with several maxima and minima.

\section{CONCLUSIONS}

1. The ${ }^{14} \mathrm{C}$ age of most Vertisols in the world was found to be Holocene. Older dates mainly reflect the age of their parent and underlying material. The expressed variability of ${ }^{14} \mathrm{C}$ age was found for the upper soil horizons: from modern up to more than $4 \mathrm{ka} \mathrm{BP}$.

2. We found the normal vertical increasing of ${ }^{14} \mathrm{C}$ age with depth in Vertisols of the world, which indicates the weak influence of pedoturbations on Vertisols formation and evolution.

However we found the lateral variability of ${ }^{14} \mathrm{C}$ age of $\mathrm{OM}$ at a similar depth in Vertisols of different gilgai positions in the North Caucasus. The trend of ${ }^{14} \mathrm{C}$ age increasing was found for corresponding depths from the microlow to microslope and the microhigh.

3. The variation of ${ }^{14} \mathrm{C}$ age is due to 1) Vertisols pedogenesis/evolution (upward lifting of older horizons towards the surface because of shearing), and 2) their modern functioning including water regime, input and lateral redistribution of fresh organic matter which support OM rejuvenation in the microlows and its preservation in the microhighs. ${ }^{14} \mathrm{C}$ inversion seems to be typical for mature Vertisols and resulted from lateral shearing and upward lifting. They seem to be most probable in soils of present or former gilgai microhighs.

4. Because of short-range microvariability Vertisols require a special method of sampling which follows their precise field investigation in a trench. This approach is needed even for Vertisols without microrelief. The best method of sampling is a complimentary sampling by profiles and by polygons.

\section{REFERENCES}

Alexandrovsky A, Chichagova O. 1998. The ${ }^{14} \mathrm{C}$ age of humic substances in paleosols. Radiocarbon 40(2): 991-7.

Arai S, Hatta T, Tanaka U, Hayamizu K, Kigoshi K, Ito O. 1996. Characterization of the organic components of an Alfisol and a Vertisol in adjacent locations in Indian semi-arid tropics using optical spectroscopy, ${ }^{13} \mathrm{C}$ NMR spectroscopy, and ${ }^{14} \mathrm{C}$ dating. Geoderma 69:5970 .

Beckmann GG, Hubble GD, Thompson CH. 1970. Gilgai forms, distribution and soil relationships in NorthEastern Australia. Paper No 2898. Symposium on soils and earth structures in arid climates. Adelaide: 88-93.

Blackburn G, Sleeman JR, Scharpenseel HW. 1979. Radiocarbon measurements and soil micromorphology as guides to the formation of gilgai at Kaniva, Victoria. Aust. J. Soil Res. 19:1-15.

Cherkinsky AE, Brovkin VA. 1993. Dynamics of radio- carbon in soils. Radiocarbon 35(3):363-7.

Chichagova OA. 1985. Radiocarbon dating of soil humus. Moscow: Nauka. 157 p.

Chichagova OA, Cherkinsky AE. 1993. Problems in radiocarbon dating of soils. Radiocarbon 35(3):351-62.

Dudal R. 1965. Dark clay soils of tropical and subtropical regions. FAO Agricultural Development Paper No 83. Rome: FAO. 161 p.

Goryachkin SV, Cherkinsky AE, Chichagova OA. 2000. The soil organic carbon dynamics in high latitudes of Eurasia using ${ }^{14} \mathrm{C}$ data and the impact of potential climate change. In: Lal R, Kimble JM, Stewart BA, editors. Global climate change and cold regions ecosystems. London, New York. p 145-61.

Kovda I, Morgun E, Alekseeva T. 1992. Development of gilgai soil cover in Central Ciscaucasia. Eurasian Soil Science 24(6):28-45.

Kovda I, Morgun E, Ryskov Ya. 1996a. Structural-functional analysis of gilgai soil microcomplex: morpho- 
logical features and moisture dynamics. Eurasian Soil Science 28(12):20-38.

Kovda I, Morgun E, Tessier D. 1996b. Etude de Vertisols a gilgai du Nord-Caucase: mecanismes de differenciation et aspects pedogeochimiques. Etude et gestion des sols 3(1):41-52.

Kovda I, Williams D, Lynn W, Morgun E. 1999. Soilgeochemical structure of Vertisols areas in temperate and subtropical climate. Proceedings of the International Conference on Genesis, Geography and Ecology of Soils. Lviv, Ukraine. p 46-8.

Scharpenseel HW Pietig F. 1973a. University of Bonn natural radiocarbon measurements V. Radiocarbon 15(1):13-41.

Scharpenseel HW Pietig F. 1973b. University of Bonn natural radiocarbon measurements VI. Radiocarbon 15(2):252-79.

Soil Survey Laboratory Methods Manual. 1996. Soil Survey Investigations Report No. 42. Version 3. USDANRCS-NSSC.

Soil Survey Staff. 1998. Key to Soil Taxonomy. USDANRCS. Washington DC: US Government Printing Office.

Stephan S, Berrier J, De Petre AA, Jeanson C, Kooistra MJ, Scharpenseel HW, Schiffmann H. 1983. Charac- terization of in situ organic matter constituents in Vertisols from Argentina, using submicroscopic and cytochemical metods - first report. Geoderma 30(1-4): 21-34.

Wilding LP, Tessier D. 1988. Genesis of Vertisols: shrink-swell phenomena. In: Wilding LP, Puentes R, editors. Vertisols: their distribution, properties, classification and management. Texas A \& M University. Technical Monograph 18:55-81.

Wilding LP, Williams D, Miller W, Cook T, Eswaran H. 1990. Close interval spatial microvariability of Vertisols: a case study in Texas. In: Kimble JM, editor. Proceedings of the Sixth International Soil Correlation Meeting. Characterization, classification and utilization of cold Aridisols and Vertisols. Lincoln, Nebraska: USDA Soil Conservation Service, National Soil Survey Center. p 232-47.

Williams D, Cook T, Lynn W, Eswaran H. 1996. Evaluating the field morphology of Vertisols. Soil Survey Horizons 37:123-30.

Yaalon DH, Kalmar D. 1978. Dynamics of cracking and swelling clay soils: displacement of skeletal grains, optimum depth of slickensides, and rate of intra-pedonic turbation. Earth Surface Processes 3:31-42. 